\title{
Pengaruh Penerapan Metode Creative Learning Terhadap Hasil Belajar Siswa Pada Mata Pelajaran Administrasi Sistem Jaringan di SMK Negeri 3 Makassar
}

\author{
Fitri $^{1}$, Alimuddin Sa'ban Miru ${ }^{2}$, Ruslan $^{3}$ \\ ${ }^{1,2,3}$ Universitas Negeri Makassar \\ ${ }^{1}$ fitrifitriffffl1@gmail.com \\ 2asmiru63@gmail.com

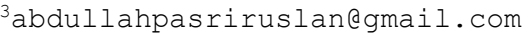

\begin{abstract}
Abstrak - Penelitian ini bertujuan : (1) Untuk mengetahui pengaruh penerapan metode Creative Learning terhadap hasil belajar siswa pada mata pelajaran Administrasi Sistem Jaringan di SMK Negeri 3 Makassar; dan (2) Untuk mengetahui besar nilai rata-rata hasil belajar siswa setelah penerapan metode Creative Learning pada mata pelajaran Administrasi Sistem Jaringan di SMK Negeri 3 Makassar. Metode penelitian yang digunakan adalah Quasi Eksperiment dengan menggunakan desain Nonequivalent Control Group Design, sampel diambil secara purposive sampling dari dua kelas yaitu kelas XI TKJ-1 sebagai kelas eksperimen yang berjumlah 34 siswa dan kelas XI TKJ-2 sebagai kelas kontrol yang berjumlah 34 siswa. Teknik pengumpulan data menggunakan instrumen digital melalui tes. Data dianalisis dengan menggunakan analisis deskriptif dan uji-t. Hasil penelitian menunjukkan bahwa; (1) Ada pengaruh penerapan metode Creative Learning terhadap hasil belajar siswa pada mata pelajaran Administrasi Sistem Jaringan di SMK Negeri 3 Makassar, dan (2) Besar nilai rata-rata hasil belajar siswa setelah penerapan metode Creative Learning pada mata pelajaran Administrasi Sistem Jaringan di SMK Negeri 3 Makassar adalah sebesar 86,76 .
\end{abstract}

Kata kunci: Metode Creative Learning, Hasil Belajar

\section{PENDAhuluan}

Pendidikan merupakan salah satu faktor yang sangat penting bagi kehidupan manusia dalam rangka mencapai cita-cita dan tujuan yang diharapkan. Oleh karena itu, pendidikan harus dilaksanakan sebaik mungkin dengan mengarahkan berbagai faktor yang menunjang terhadap peningkatan kualitas Pendidikan. Guru merupakan faktor pendorong untuk mewujudkan tujuan dan sarana Pendidikan. Guru dituntut untuk memiliki kemampuan dalam menciptakan pembelajaran yang baik dan harus mampu mengelolah sumber yang ada, menyusun perencanaan, dan mampu meningkatkan kemampuan dalam memberikan pelayanan yang baik terhadap peserta didik sehingga terciptanya pembelajaran yang baik.

Sejalan dengan hal tersebut, dalam Undang-undang No. 20 Tahun 2003 tentang sistem pendidikan nasional secara tegas menyatakan bahwa "Pendidikan merupakan usaha sadar dan terencana untuk mewujudkan suasana belajar dan proses pembelajaran agar siswa secara aktif mengembangkan potensi dirinya untuk memiliki kekuatan spiritual keagamaan, pengendalian diri, kepribadian, kecerdasan, akhlak mulia, serta keterampilan yang diperlukan dirinya, masyarakat, bangsa, dan negara" (Sistem Pendidikan Nasional pasal 1 ayat 1 2003: 20).

Pemerintah mengusahakan Pendidikan mulai dari Pendidikan taman kanak-kanak sampai perguruan tinggi untuk menjawab tujuan yang tersurat pada pembukaan undang-undang 1945 yaitu mencerdaskan kehidupan bangsa. Tujuan

pendidikan yang harus dicapai adalah tujuan yang berakar dari budaya bangsa Indonesia dan sesuai dengan dasar negara seperti tercantum dalam undang-undang No. 20

Tahun 2003 tentang sistem Pendidikan nasional, Bab 1 Pasal 1 Ayat (2) bahwa "Pendidikan Nasional adalah Pendidikan yang berakar pada kebudayaan bangsa Indonesia dan yang berdasarkan pada undang-undang Dasar 1945". Pernyataan ini mengandung arti bahwa semua aspek yang terdapat dalam sistem Pendidikan nasional akan mencerminkan aktivitas yang dijiwai oleh Pancasila dan UUD 1945 dan berakar pada kebudayaan bangsa Indonesia.

Pendidikan menengah kejuruan adalah pendidikan pada jenjang pendidikan menengah yang mengutamakan pengembangan kemampuan siswa untuk melaksanakan jenis pekerjaan tertentu. Pendidikan menengah kejuruan mengutamakan penyiapan siswa untuk memasuki lapangan kerja serta mengembangkan sikap professional. Sesuai dengan bentuknya, sekolah menengah kejuruan menyelenggarakan program-program pendidikan yang disesuaikan dengan jenis-jenis lapangan kerja (Peraturan Pemerintah Nomor 29 Tahun 1990).

Sekolah Menengah Kejuruan (SMK) merupakan satuan pendidikan menengah yang mempersiapkan siswa-siswinya bekerja pada bidang-bidang tertentu sesuai keahlian program bidang studi masing-masing. Tujuan dari pendidik Sekolah Menengah Kejuruan adalah menyiapkan siswa agar memiliki kepribdian yang tinggi diikuti dengan moral, etika, dan karakter diri yang baik. Sesuai dengan tujuan tersebut, dalam proses belajar mengajar memiliki komponen-komponen penting. Komponen-komponen penting dalam proses belajar mengajar yaitu guru, peserta didik, metode mengajar, media dan evaluasi (Herawan, 2019).

Guru sebagai pelaksana, harus dapat menentukan pilihannya dengan mempertimbangkan semua aspek yang menunjang tercapainya tujuan, tetapi kenyataannya saat ini banyak kegiatan belajar mengajar yang tidak mampu mencapai tujuan pembelajaran. Salah satu komponen penting bagi proses pembelajaran adalah kemampuan guru dalam menggunakan metode pembelajaran. Pemilihan metode pembelajaran yang tepat akan meningkatkan apresiasi, imajinasi, kreativitas dan kemampuan berpikir siswa yang akan berpengaruh pada hasil belajar siswa (Hamalik, 2008).

Menurut Guilford dalam Munandar (2004), penelitian terkait kreativitas masih sangat kurang. Proses untuk berpikir kreatif masih sangat jarang dilatih khususnya di Indonesia. Pengembangan kreativitas ditelantarkan dalam pendidikan formal, padahal kreativitas sangat bermakna bagi pengembangan potensi anak secara utuh. Oleh karena itu, guru harus mampu menciptakan proses pembelajaran yang kreatif melalui metode pembelajaran.

Metode Creative Learning atau biasa disebut pembelajaran kreatif merupakan proses pembelajaran yang mengharuskan guru dapat memotivasi dan memunculkan kreativitas peserta didik selama proses pembelajaran berlangsung, misalnya kerja kelompok, pemecahan masalah dan sebagainya. Metode Creative 
Learning mengharuskan guru untuk mampu merangsang peserta didik memunculkan kreativitas, baik dalam konteks kreatif berpikir maupun dalam konteks melakukan sesuatu. Dengan menerapkan metode creative learning diharapkan mampu membuat siswa menjadi aktif, kreatif, antusias, dalam pembelajaran sehingga mempengaruhi peningkatan hasil belajar siswa (Rusman, 2014).

Hasil belajar mempunyai peranan penting dalam proses pembelajaran. Rusman (2015), mengatakan bahwa hasil belajar adalah sejumlah pengalaman yang diperoleh siswa yang mencakup ranah kognitif, afektif, dan psikomotorik. Selain itu, Hamzah (2010), berpendapat bahwa hasil belajar adalah perubahan perilaku yang relatif menetap dalam diri seseorang sebagai akibat dari interaksi seseorang dengan lingkunganya.

Berdasarkan hasil observasi yang dilakukan oleh peneliti pada tanggal 20 Maret 2020 di ruangan ketua program kompetensi keahlian Teknik Komputer dan Jaringan SMK Negeri 3 Makassar, peneliti melakukan wawancara dengan Ibu Agustiah, S.Pd., M.Pd. selaku ketua program kompetensi keahlian Teknik Komputer dan Jaringan (TKJ) di SMK Negeri 3 Makassar. Adapun hasil wawancara yaitu dalam proses pembelajaran terdapat beberapa masalah dalam pelaksanaan pembelajaran dikelas khususnya pada mata pelajaran Administrasi Sistem Jaringan Kelas XI TKJ 1 dan XI TKJ 2 yaitu rendahnya hasil belajar siswa. Rata-rata nilai siswa masih dibawah Kriteria Ketuntasan Minimal (KKM) untuk Mata Pelajaran Administrasi Sistem Jaringan di Program Studi TKJ XI pada tahun 2019/2020 yakni 70. Hal ini disebabkan guru cenderung menggunakan metode konvensional, sehingga siswa tidak termotivasi untuk ikut aktif dalam mengikuti proses pembelajaran. Hal ini mengakibatkan siswa menjadi pasif, kurang bersemangat dalam mengikuti kegiatan belajar mengajar dan cenderung mengantuk di dalam kelas. Dengan menerapkan metode yang monoton seperti itu, mengakibatkan paradigma mengajar masih tetap dipertahankan dan belum berubah menjadi paradigma membelajarkan siswa. Dalam kegiatan belajar mengajar, interaksi hanya berjalan satu arah, yakni dari guru saja (teacher centered).

Metode konvensional ini umumnya guru yang sangat aktif dan memegang peranan utama. Akibat dari penggunaan metode ini daya pikir atau pemahaman siswa terhadap materi yang telah diajaekan kurang dapat berkembang. Kurangnya pemahaman siswa terhadap materi yang diajarkan oleh guru mengakibatkan hasil belajar yang dicapai siswa belum optimal. Maka dari itu, salah satu alternatif yang dapat digunakan untuk meningkatkan hasil belajar siswa adalah dengan menerapkan metode yang dapat menarik perhatian dan minat belajar siswa, melibatkan siswa secara langsung, menuntut peran siswa untuk aktif dan terlebih lagi meminimalisir kesenjangan hasil belajar siswa.

Berdasarkan latar belakang di atas, maka diadakan penelitian yang berjudul "Pengaruh Penerapan Metode Creative Learning Terhadap Hasil Belajar Siswa Pada Mata Pelajaran Administrasi Sistem Jaringan di SMK Negeri 3 Makassar".

\section{METODE PENELITIAN}

Jenis penelitian ini adalah penelitian kuantitatif menggunakan eksperimen semu (Quasi Eksperiment). Quasi eksperimen digunakan untuk mengetahui pengaruh penerapan metode creative learning terhadap hasil belajar siswa pada mata pelajaran Administrasi Sistem Jaringan di SMK Negeri 3 Makassar.

Desain penelitian yang digunakan adalah Nonequivalent Control Group Design dengan membagi kelompok eksperimen dan kelompok kontrol. Kelompok eksperimen diberi perlakuan dengan menerapkan metode Creative Learning sedangkan kelompok kontrol diberi perlakuan dengan menerapkan metode konvensional. Kedua kelompok tersebut diberi pretest, kemudian diberikan perlakuan (treatment), dan terakhir diberikan posttest.
Populasi dalam penelitian ini adalah siswa kelas XI SMK Negeri 3 Makassar. Teknik pengambilan sampel dalam penelitian ini menggunakan teknik purposive sampling. Adapun sampel yang diambil adalah kelas XI TKJ-1 sebanyak 34 orang siswa yang merupakan kelompok eksperimen dan kelas XI TKJ-2 sebanyak 34 orang siswa yang merupakan kelompok kontrol.

Penelitian ini terdapat dua variabel yaitu Variabel independen atau bebas (X) dalam penelitian ini adalah metode Creative Learning dan Variabbel dependen atau terikat dalam (Y) dalam penelitian ini adalah hasil belajar siswa Kelas XI TKJ SMK Negeri 3 Makassar.

Teknik pengumpulan data adalah teknik atau cara-cara yang dapat digunakan oleh peneliti untuk mengumpulkan data. Teknik pengumpulan data yang digunakan adalah teknik pengumpulan data yang tepat, sehingga benar-benar terdapat data yang valid dan reliabel. Dalam penelitian ini untuk memperoleh data-data yang sesuai dengan tujuan penelitian maka teknik pengumpulan data diantaranya:

a. Tes

Tes merupakan pertanyaan yang digunakan untuk mengukur kemampuan siswa dalam menerima pembelajaran. Tes dilakukan dua kali yaitu pretest (tes awal) dan posttest (tes awal). Tes digunakan untuk mengukur hasil belajar siswa pada mata pelajaran Administrasi Sistem Jaringan dengan penerapan metode Creative Learning dan metode konvensional. Bentuk tes berupa soal Pilihan Ganda.

b. Dokumentasi

Teknik dokumentasi digunakan dengan menelaah dokumendokumen/ data sebagai bukti akurat yang mendukung dalam penelitian ini. Data yang ditelaah meliputi data jumlah siswa, fotofoto yang diambil saat penelitian dan lain sebagainya.

1. Uji Instrumen Penelitian

a. Uji Validitas Instrumen

Validasi instrumen yang akan digunakan dalam penelitian ini yaitu, validasi isi yang dinilai oleh ahli. Validitas isi menunjukkan bahwa instrumen yang disusun sesuai dengan kurikulum, materi dan tujuan pembelajaran yang diharapkan. Analisis untuk validitas instrumen dilakukan dengan skala likert.

Pengkategorian hasil analisis ahli instrumen tes dilakukan berdasarkan kriteria pengkategorian kualitas instrumen yang diadaptasi dari Azwar (2012), dapat dilihat pada tabel 3.4

Tabel 1. Kategori Pemberian Skor Alternatif Jawaban Ahli Instrumen

\begin{tabular}{|c|c|}
\hline Skor & Kategori \\
\hline $4,2 \leq M \leq 5,0$ & Sangat Valid \\
\hline $3,4 \leq M<4,2$ & Valid \\
\hline $2,6 \leq M<3,4$ & Cukup \\
\hline $1,8 \leq M<2,6$ & Tidak Valid \\
\hline $1,0 \leq M<1,8$ & Sangat Tidak Valid \\
\hline
\end{tabular}

Uji validasi instrumen tes terdapat beberapa aspek, yaitu aspek petunjuk, aspek isi dan aspek bahasa. Setiap aspek kemudian dijabarkan menjadi indikator yang selanjutnya dibagi menjadi beberapa butir pertanyaan pada instrumen penelitian. Data dari hasil validasi ahli instrumen berupa skor yang selanjutnya dikalkulasikan dan menghasilkan bahwa kuisioner yang akan digunakan telah layak digunakan.

b. Uji Reliabilitas Instrumen Penelitian

Arikunto (2013) menyatakan bahwa, uji reliabilitas menunjukkan suatu pengertian bahwa suatu instrumen cukup dapat dipercaya untuk digunakan sebagai alat pengumpul data. 
Dalam penelitian ini data yang diperoleh dianalisis menggunakan Teknik analisis statistik deskriptif dan analisis statistik inferensial.

1. Analisis Statistik Deskriptif

Analisis deskriptif digunakan untuk mengolah data untuk mengetahui besar nilai rata-rata hasil belajar melalui metode Creative Learning pada mata pelajaran Administrasi Sistem Jaringan.

2. Analisis Statistik Inferensial

Analisis statistik inferensial berupa uji normalitas, uji homogenitas dan uji hipotesis (uji-t).

\section{HASIL DAN PEMBAHASAN}

Hasil penelitian ini merupakan hasil penelitian kuantitatif yang dinyatakan dalam bentuk angka untuk mengetahui pengaruh penerapan metode Creative Learning terhadap hasil belajar siswa pada mata pelajaran Administrasi Sistem Jaringan di SMK Negeri 3 Makassar. Penyajian hasil penelitian ini dibedakan atas penyajian data nilai siswa Kelompok Kontrol (Kelas TKJ-2) dan Kelompok Eksperimen (Kelas TKJ-1). Penyajian nilai siswa masing-masing kelas terdiri dari hasil pretest dan posttest.

Deskriptif data berfungsi untuk menggambarkan data yang telah diperoleh dari sumber data di lapangan. Data yang sudah diperoleh, disajikan dalam bentuk tabel, mean, modus, median, simpangan baku atau standar deviasi, nilai tertinggi dan nilai terendah. Data tersebut kemudian dianalisis guna menjawab hipotesis.

Kegiatan penelitian yang dilakukan terdiri dari pretest, treatment dan posttest. Pertemuan pertama dilakukan tes awal (pretest) kepada kedua kelompok sampel baik kelompok kontrol maupun kelompok eksperimen. selanjutnya diberikan perlakuan (treatment) pada kedua kelompok yaitu kelompok kontrol diberi perlakuan dengan penerapan metode konvensional dan kelompok eksperimen diberi perlakuan dengan metode creative learning. Kemudian pada pertemuan terakhir dilakukan tes akhir (posttest) pada kedua kelompok. Berdasarkan data penelitian yang telah diolah diperoleh perhitungan dasar statistik untuk kelompok kontrol dan kelompok eksperimen sebagai berikut.

Tabel 2. Deskriptif Data Hasil Belajar Kelompok Kontrol dan Kelompok Eksperimen

\begin{tabular}{|c|l|c|c|c|c|}
\hline \multirow{2}{*}{ No } & \multirow{2}{*}{ Statistik } & \multicolumn{2}{|c|}{$\begin{array}{c}\text { Hasil Belajar } \\
\text { Kelompok } \\
\text { Kontrol }\end{array}$} & \multicolumn{2}{c|}{$\begin{array}{c}\text { Hasil Belajar } \\
\text { Kelompok } \\
\text { Eksperimen }\end{array}$} \\
\cline { 3 - 6 } & Pretest & Posttest & Pretest & Posttest \\
\hline 1 & $\begin{array}{l}\text { Jumlah } \\
\text { Sampel }\end{array}$ & 34 & 34 & 34 & 34 \\
\hline 2 & $\begin{array}{l}\text { Skor } \\
\text { Tertinggi } \\
\text { (Max) }\end{array}$ & 50 & 70 & 70 & 100 \\
\hline 3 & $\begin{array}{l}\text { Skor } \\
\text { terendah } \\
\text { (min) }\end{array}$ & 10 & 30 & 10 & 70 \\
\hline 4 & $\begin{array}{l}\text { Skor rata-rata } \\
\text { (mean) }\end{array}$ & 28,53 & 48,24 & 32,06 & 86,76 \\
\hline 5 & $\begin{array}{l}\text { Titik tengah } \\
\text { (median) }\end{array}$ & 30,00 & 50,00 & 30,00 & 90,00 \\
\hline & $\begin{array}{l}\text { Simpangan } \\
\text { Baku } \\
\text { standar } \\
\text { deviation) }\end{array}$ & 10,190 & 10,863 & 13,434 & 10,932 \\
\hline
\end{tabular}

Hasil uji analisis statistik deskriptif dilakukan dengan tujuan untuk mengetahui besar nilai rata-rata hasil belajar siswa setelah penerapan metode creative learning. Berikut tabel nilai rata-rata setelah penerapan metode creative learning (Posttest Kelompok Eksperimen).

Tabel 3. Nilai Rata-Rata Hasil Belajar Posttest Kelompok Eksperimen

\begin{tabular}{|c|l|c|c|}
\hline No & \multicolumn{1}{|c|}{ Kelas } & N & $\begin{array}{c}\text { Rata-Rata } \\
\text { (Mean) }\end{array}$ \\
\hline 1 & $\begin{array}{l}\text { Posttest Eksperimen XI } \\
\text { TKJ-1 }\end{array}$ & 34 & 86,76 \\
\hline
\end{tabular}

Sumber : Hasil Olah Data 2021

Uji prasyarat analisis dilakukan dengan tujuan untuk mengetahui apakah data yang dikumpulkan memenuhi persyaratan untuk dianalisis dengan teknik yang telah direncanakan. Uji tersebut diantaranya:

a. Uji Normalitas

Uji normalitas yang digunakan dalam penelitian ini yakni metode perhitungan Kolmogrov-Smirnov dengan kriteria jika nilai signifikansi (sig).> 0,05, maka data dinyatakan berdistribusi normal. Namun, jika nilai signifikansi (sig), $<0,05$, maka data dinyatakan tidak berdistribusi normal dengan hipotesis: $\mathrm{H}_{0}$ : data berasal dari populasi yang berdistribusi normal; dan $\mathrm{H}_{1}$ : data tidak berasal dari populasi yang berdistribusi normal. Penggunaan uji normalitas dengan menggunakan perhitungan Kolmogrov-Smirnov dikarenakan sampel masing-masing kelas $<50$ orang siswa. Adapun uji normalitas untuk data yang berasal dari pretest posttest kelompok kontrol (Kelas TKJ-2) dan Kelompok Eksperimen (Kelas TKJ-1) sebagai berikut.

1. Uji Normalitas Hasil Pretest dan Posttest

Uji normalitas yang digunakan dalam penelitian ini yakni metode perhitungan Kolmogrov-Smirnov dengan kriteria jika nilai signifikansi (sig). $>0,05$, maka data dinyatakan berdistribusi normal. Namun, jika nilai signifikansi (sig). $<0,05$, maka data dinyatakan tidak berdistribusi normal dengan hipotesis: $\mathrm{H}_{0}$ : data berasal dari populasi yang berdistribusi normal; dan $\mathrm{H}_{1}$ : data tidak berasal dari populasi yang berdistribusi normal. Adapun uji normalitas untuk data yang berasal dari kelas pretest posttest kelompok kontrol (Kelas TKJ-2) sebagai berikut.

Tabel 4. Uji Normalitas Pretest - Posttest kelompok Kontrol

\begin{tabular}{|c|c|c|c|c|}
\hline No & Data & $\begin{array}{c}\text { Kolmogrov- } \\
\text { Smirnov } \boldsymbol{Z}\end{array}$ & A & Sig \\
\hline 1 & Pretest & 1,81 & 0,05 & 0,06 \\
\hline 2 & Posttest & 1,82 & 0,05 & 0,06 \\
\hline
\end{tabular}

2. Uji Normalitas Hasil Pretest dan Posttest

Berdasarkan hasil pengolahan data SPSS 24, diperoleh data sebagai berikut.

Tabel 5. Uji normalitas dari Pretest - Posttest Kelompok Eksperimen

\begin{tabular}{|c|c|c|c|c|}
\hline No & Data & $\begin{array}{c}\text { Kolmogrov- } \\
\text { Smirnov } \boldsymbol{Z}\end{array}$ & $\mathbf{A}$ & Sig \\
\hline 1 & Pretest & 1,79 & 0,05 & 0,08 \\
\hline 2 & Posttest & 1,81 & 0,05 & 0,06 \\
\hline
\end{tabular}

Sumber : Hasil Olah Data 2021

Berdasarkan uji normalitas di atas dapat disimpulkan bahwa hasil pretest dan postest kedua kelompok eksperimen berdistribusi normal. Selanjutnya akan dilakukan pengujian homogenitas dari hasil pretest dan postest kedua kelompok kontrol (Kelas TKJ-2) dan Kelompok Eksperimen (Kelas TKJ-1).

b. Uji Homogenitas

Uji homogenitas yang digunakan dalam penelitian ini yakni metode perhitungan Test of Homogeneity of Variance dengan kriteria jika nilai signifikansi $>0,05$, maka data dinyatakan data bersifat homogen. Namun, jika nilai signifikansi $<0,05$, maka data dinyatakan tidak homogen dengan hipotesis: $\mathrm{H}_{0}$ : data bersifat 
homogen; dan $\mathrm{H}_{1}$ : data tidak homogen. Berdasarkan hasil pengolahan data SPSS 24 diperoleh data sebagai berikut.

\begin{tabular}{|c|c|c|c|c|}
\hline $\begin{array}{c}\text { Tabel 6. Uji Homogenitas } \\
\text { Belajar }\end{array}$ & $\begin{array}{c}\text { Levene } \\
\text { Statistic }\end{array}$ & Df & A & Sig \\
\hline $\begin{array}{c}\text { Based on } \\
\text { mean }\end{array}$ & 0,572 & 3 & 0.05 & 0,634 \\
\hline
\end{tabular}

Sumber : Hasil Olah Data 2021

Pretest kelas kelompok Kontrol dan kelompok eksperimen memenuhi syarat kriteria uji homogenitas sehingga dapat disimpulkan bersifat homogen. Hal ini menunjukkan bahwa langkah selanjutnya yakni menguji hasil posttest pada uji beda atau uji hipotesis.

c. Uji Hipotesis

1. Uji-t

Berdasarkan uji prasyarat analisis statistik, diperoleh bahwa hasil belajar kedua kelas pada penelitian ini berdistribusi normal dan bersifat homogen. Oleh karena itu, pengujian hipotesis dapat dilakukan dengan menggunakan rumus uji-t yaitu independent sample t-test. Pengujian hipotesis ini dilakukan untuk mengetahui dugaan sementara yang dirumuskan. Berikut hipotesis yang ditetapkan sebelumnya:

1) Hipotesis nol $\left(\mathrm{H}_{0}\right)$ ditolak apabila nilai signifikansi lebih besar daripada probabilitas signifikansi (Asymp.sig. $>\alpha$ ). Artinya tidak ada pengaruh hasil belajar yang signifikan pada kelompok kontrol setelah penerapan metode konvensional pada mata pelajaran Administrasi Sistem Jaringan di SMK Negeri 3 Makassar.

2) Hipotesis alternatif $\left(\mathrm{H}_{\mathrm{a}}\right)$ diterima apabila nilai signifikansi lebih kecil daripada probabilitas signifikansi (Asymp.sig. $<\alpha$ ). Artinya ada pengaruh hasil belajar yang signifikan pada kelompok eksperimen setelah penerapan metode Creative Learning pada mata pelajaran Administrasi Sistem Jaringan di SMK Negeri 3 Makassar.

Berikut adalah hasil independent sample t-test dengan SPSS Versi 24.

\begin{tabular}{|c|c|c|c|c|c|}
\multicolumn{6}{c|}{ Tabel 7. Independent Sample T-Test } \\
\hline \multirow{2}{*}{ Postest } & F & Sig. & T & Df & $\begin{array}{c}\text { Sig.(2- } \\
\text { tailed) }\end{array}$ \\
\cline { 2 - 7 } & 3,62 & 0,549 & $-14,577$ & 66 & 0,0001 \\
\hline
\end{tabular}

Sumber : Hasil Olah Data 2021

Berdasarkan tabel 4.10 diperoleh nilai t hitung $=-14,577$ dan nilai sig. $=0,0001$, karena sig $<\alpha$ yaitu $0,0001<0,05$, dengan demikian $\mathrm{H}_{0}$ ditolak dan $\mathrm{H}_{\mathrm{a}}$ diterima. Hal ini menunjukkan bahwa ada perbedaan yang signifikan antara rata-rata hasil belajar posttest kelompok eksperimen setelah penerapan metode creative learning dengan rata-rata hasil belajar posttest kelompok kontrol setelah penerapan metode konvensional.

\section{KESIMPULAN}

Berdasarkan hasil penelitian dan pembahasan, berikut beberapa kesimpulan mengenai penelitian tentang "Pengaruh Penerapan Metode Creative terhadap Hasil Belajar Siswa pada Mata Pelajaran Administrasi Sistem Jaringan di SMK Negeri 3 Makassar"

1. Berdasarkan hasil penelitian yang telah dilakukan dapat disimpulkan bahwa ada pengaruh penerapan metode Creative Learning terhadap hasil belajar siswa pada mata pelajaran Administrasi Sistem Jaringan di SMK Negeri 3 Makassar. Hal ini berdasarkan hasil uji hipotesis pada data posttest diperoleh nilai t-hitung $=-14,577$ dengan nilai signifikansi (2-tailed) sebesar 0,0001 dibandingkan dengan probabilitas sebesar 0,05 atau sig. $<\alpha(0,0001<0,05)$ dengan demikian $\mathrm{H}_{0}$ ditolak dan $\mathrm{H}_{\mathrm{a}}$ diterima yang berarti ada pengaruh penerapan metode Creative
Learning terhadap hasil belajar siswa pada mata pelajaran Administrasi Sistem Jaringan di SMK Negeri 3 Makassar.

2. Besar nilai rata-rata hasil belajar siswa setelah penerapan metode Creative Learning pada mata pelajaran Administrasi Sistem Jaringan di SMK Negeri 3 Makassar adalah sebesar 86,76 .

\section{DAFTAR PUSTAKA}

[1] Arikunto, Suharsimi. 2013. Prosedur Penelitian, suatu pendekatan praktis. Jakarta: PT. Rineka Cipta

[2] Azwar, S. 2012. Realibitas dan Validitas. Yogyakarta: Pustaka Pelajar

[3] Hamzah B. Uno, M. 2010. Teori Motivasi dan Pengukurannya. Jakarta: PT. Bumi Aksara

[4] Hamalik, Oemar. 2008. Proses Belajar Mengajar. Jakarta: Bumi Aksara.

[5] Herawan, Endang \& Suryadi. 2019. Efektivitas Manajemen Mutu Pembelajaran Guru Bidang Produktif Di Sekolah Menengah Kejuruan. http://adpend.upi.edu/blog/efektivitas-manajemen-mutupembelajaran-guru-bidang-produktif-di-sekolahmenengah-kejuruan/di akses pada 1 maret 2020.

[6] Munandar, Utami. 2004. Pengembangan Kreativitas Anak berbakat. Jakarta: Rineka Cipta.

[7] Rusman. 2014. Metode-Metode Pembelajaran: Mengembangkan Profesionalisme Guru. Jakarta: Rajawali Pers.

[8] Rusman. 2015. Pembelajaran Tematik Terpadu: Teori, Praktik dan Penilaian. Jakarta: PT. Raja Grafindo Persada. 